\title{
Phenolic Compositions of Litchi Shoot Tips and Zygotic Embryos Collected in Different Months and Their Effects on the Explant Browning and Its Control
}

\author{
D. K. Das*, A. Rahman \\ Department of Biotechnology, T. M. Bhagalpur University, Bhagalpur, India \\ Email: *dilipdas1@live.com
}

How to cite this paper: Das, D. K., \& Rahman, A. (2016). Phenolic Compositions of Litchi Shoot Tips and Zygotic Embryos Collected in Different Months and Their Effects on the Explant Browning and Its Control. Advances in Anthropology, 6, 7392. http://dx.doi.org/10.4236/aa.2016.64008

Received: September 6, 2016 Accepted: September 23, 2016

Published: September 26, 2016

Copyright $\odot 2016$ by authors and Scientific Research Publishing Inc. This work is licensed under the Creative Commons Attribution International License (CC BY 4.0).

http://creativecommons.org/licenses/by/4.0/ (c) (i) Open Access

\begin{abstract}
In the research it was examined the changes in total phenolic contents and seven major phenolic compounds (gallic acids, $+(-)$ catechin, catechol, Chlorogenic acid, o-coumaric acid, rutin and quercetin) of two litchi cultivars (Purbi and Bedana) shoot tips and fruits (for zygotic embryos) collected in different months, in order to determine their effects on the explants browning during establishment stage of shoot tip culture. The concentrations of phenolic compounds varied depending on the cultivars and the months. Phenolic compounds showed various correlation coefficients with the explants browning. Total phenolic content and some individual phenolic compounds including $+(-)$ catechin, catechol, gallic acid, chlorogenic acid and rutin quantified in this study showed significant positive correlations with the explants browning, while o-coumaric acid and quercetin did not exhibit any significant one. According to our results, explants browning are affected by the phenolic compounds at different ranges. In both litchi cultivars, shoot tips and fruits (for zygotic embryos) collected in March exhibited the lowest explants browning during the establishment stage as compared to those collected in the other months. So it may be possible to increase the success of shoot tip and zygotic embryo culture with the selection of the most suitable terms of explants collection. Browning of explants could be controlled by the use of antioxidants both in semi-solid and liquid culture.
\end{abstract}

\section{Keywords}

Phenolic Compounds, Browning, Litchi Cvs Purbi \& Bedana, Shoot Tips \& Zygotic Embryos 


\section{Introduction}

Litchi (Litchi chinensis Sonn.) is a delicious nut fruit and belongs to soapberry family Sapindaceae which are tree species. Both shoot tip and zygotic embryos are mainly used in in-vitro cultures for regeneration and mass scale production of litchi contains a high amount polyphenolics which are used as defense mechanism in plants, upon oxidation by enzyme polyphenol oxydase turns browning of the explants and so explants cells are unable to grow in in-vitro conditions. So it is essential to study the composition of polyphenols which cause browning and control of it for the in-vitro culture of explants. During the establishment stage of in-vitro culture, oxidative browning of explants is one of the main drawbacks. Browning is mainly due to the presence of phenolics, released from the cut surfaces of the explants (Hu \& Wang, 1983; Lux-Endrich et al., 2000). It may be a natural defense mechanism in plants against invasion by pathogens through the wound. Releasing phenolics from cut surface to the culture medium show the phytotoxic effect. The oxidized products not only may contribute to failure of the explants development, but also may lead to the death of explants (Bhat \& Chandel, 1991; Hu \& Wang, 1983). Like other woody species, litchi tissues also exhibit high levels of polyphenols and tannins (Harding \& Roubelakis-Angelakis, 1994) and lipid peroxidation products (Benson \& Roubelakis-Angelakis, 1992). Major thrust of litchi research has been on prevention of physiological browning and retention of bright red coloration of litchi fruits in several countries (Sarin et al., 2008). During zygotic embryo excision, culture secretes polyphenolics which cause browning of explants after oxidation (Kantharajah et al., 1992). Litchi pericarp browning is a major factor to limit storage and transportation of post harvest litchi fruit. Variations in browning substrates such as (-) epicatechin in pericarp tissue of litchi fruit development is due to changes in the activities of Polyphenoloxidase, Peroxidase and Phenylalanine ammonialyse (Sun et al., 2009). In litchi cultured explants secretes phenolic substances into the medium, which cause browning due to oxidation of phenols and formation of quinines; the toxins which effect the growth of cultured explants and browning were controlled by the use of antioxidants viz. activated charcoal, citric or ascorbic acid (Chanana \& Gill, 2008). In litchi (Litchi chinensis Sonn.) cv. Seedless, the problems of microbial contamination, phenol exudation and explants browning were controlled to a great extent by using mercuric chloride or sodium hypochlorite (Chandra \& Padari, 1999). Seedling explants of Nephelium lappaceum L. can be initiated into culture but they produce large quantities of phenolics and do not grow well. Thus, for in-vitro conservation and genetic improvement of $N$. lappaceum, it is important to establish an efficient tissue culture protocol for complete plantlet formation and activated charcoal is used for the adsorption of phytotoxic exudates such as phenolics (Chew et al., 2008). In other tropical tree species also have the same phenolic problems like Mango tissues which have also high phenolic exudation owing to activation of oxidative enzyme system during the excision of plants, explants browning, deep seated contamination, medium discoloration and slow in-vitro growth response have made it an ordeal for workers working on this crop (Krishna, 2008). In guava also phenolic problem can be controlled by the fortification 
of $500 \mathrm{mg}$ citric acid, an oxidant to the MS (Murashige \& Skoog, 1962) media and initial incubation of cultures in complete dark for 24 hrs showed substantial reduction in phenolic browning of media and higher survival of explants (Mishra et al., 2007). In Annona species, too, have been seen the phenolic problem, browning, necrosis and death of explants during in-vitro culture (Rasar et al., 1995). One of the major problems in the micropropagation of lychee is the secretion of polyphenols into the medium by the tissues. Thus polyphenols undergo oxidation to produce substances that kill the tissues (Kantharajah et al., 1992).

Some factors including type of explants, light exposure, age and vigour of the donor plants, source of explants, genotype, and size of explants affect the controlling of explants browning (Roussos \& Pontikis, 2001b; Tangolar et al., 1999; Thomas \& Ravindra, 1997; Yu \& Meredith, 1986). The time in a year for explants collection is also another important factor that influences to make the explants brown. Different antioxidants i.e. ascorbic acid, citric acid in isolation and in combination form, activated charcoal and L-cystein- $\mathrm{HCl}$ prevent browning of tissues and death of cells. Litchi produces a large amount of polyphenolics (Das et al., 1999a, b; Puchooa, 2004) as defense mechanism to save the tissue from entry of foreign particles. While incising these polyphenolics by the oxidation of polyphenoloxidase enzyme, polyphenol turns into brown compound (melanin pigment) which necroses the cell and later on the cell dies and further the growth of another cell is prevented both in liquid and semi-solid medium under in-vitro conditions. Due to browning, cells are unable to proliferate in the medium and regenerate into plant. So it is very essential to control the browning which impairs the growth of cells either in tissues or cell suspension cultures. It has been reported that Activated Charcoal when it is added to MS medium, it adsorbs polyphenolics compounds and browning can be controlled in litchi as has been seen in grape (Das et al., 2002). Even in oak polyvinylpyrrolidone, ascorbic acid, cysteine and citric acid can prevent the browning (Toth et al., 1993). If ascorbic acid (antioxidant) is added to the medium, it checks the browning of the explants and stimulates the shoot growth (Kotsias \& Roussos, 2001). $\mathrm{AgNO}_{3}$ also can check the browning process in many plant species (Das et al., 2002; Kotsias \& Roussos, 2001). L-cysteine which is also an antioxidant controls the browning of Soybean (Olhoft \& Somers, 2001).

The aim of the present work was to investigate the fluctuation and distribution of some phenolic compounds in two different litchi cultivars (Purbi and Bedana) shoot tips and fruits (for zygotic embryos) collected at different months in order to determine their possible effects on the explants browning in the establishment stage of shoot tips and zygotic embryos cultures and control of browning.

\section{Material and Methods}

\subsection{Preparation of Plant Materials}

$1-2 \mathrm{~cm}$ long shoot tips and fruits (for zygotic embryos) were collected of both cultivars (Purbi and Bedana) of litchi growing at Horticulture Division, Bihar Agricultural College, Sabour, Bhagalpur, Bihar, INDIA. Both shoot tips and fruits (for zygotic embryos) 
were taken with a 15 days interval from March to June because both initiated in the same time and in this duration phenolic concentrations are low and browning of explants during excision could be controlled under in-vitro condition. These immature fruits and shoot tips were washed in running tap water for the removal of dust particles. Followed by these immature litchi fruits and shoot tips were dipped in to tap water mixed with 2 - 4 drops of Tween 20 and swirled so that foam were formed and remained there for 6 - 7 minutes after that these fruits and shoot tips were taken out, washed in running tap water and again dipped them in $1 \%$ bavistin for removal of fungal surface contamination. Followed by these immature Litchi fruits and shoot tips were dipped for $10 \mathrm{~min}$ in sodium hypochlorite (1\% activated chlorine) containing a few drops of Tween 20, rinsed three times in sterile-distilled water and again dipped in $0.1 \% \mathrm{HgCl}_{2}$ for $5-7$ minutes under sterile condition and remained there for $5-6 \mathrm{mi}$ nutes. Followed by $\mathrm{HgCl}_{2}$ was decanted, rinsed thrice in autoclaved glass distilled water and then surface sterilized fruits wall were removed with the scalpel blade and both zygotic embryos and shoot tips were taken out in sterile condition. Now both explants (zygotic embryos and shoot tips) were ready for experiments.

\section{Formulation of media used in the experiments}

Different media which are used in these experiments have been formulated in (Table 1).

\section{Shoot tip and zygotic embryo culture}

50 shoot tips were excised under aseptic conditions and inoculated on medium MS1 (see Table 1). Followed by inoculation, the cultures were incubated at $25^{\circ} \mathrm{C} \pm 2{ }^{\circ} \mathrm{C}$ under cool-white fluorescent illumination with $16 \mathrm{~h}$ day-length. After three weeks, the percentages of browning of explants were determined. The dead explants because of the browning were discarded, while surviving explants were sub-cultured to the fresh media.

\section{Determination of total phenolic content}

For total phenolic extraction, shoot tips and zygotic embryos were homogenized with $50 \%$ ethanol in water and left for $2 \mathrm{~h}$ in the dark. After filtration the concentration of

Table 1. Formulation of different media used in these experiments with period of culture.

\begin{tabular}{|c|c|c|c|}
\hline $\begin{array}{c}\text { Serial } \\
\text { Number }\end{array}$ & Name of Media & Media composition and culture condition & $\begin{array}{l}\text { Period of Culture } \\
\quad \text { (weeks) }\end{array}$ \\
\hline 1 & $\begin{array}{l}\text { MS1 for semi-solid } \\
\text { culture }\end{array}$ & $\begin{array}{l}\text { MS basal medium (Murashige \& Skoog, 1962) supplemented with } 2.5 \mathrm{mgl}^{-1} \mathrm{BA} \text { (6-benzyladenine), } \\
0.5 \mathrm{mgl}^{-1} \mathrm{GA}_{3}, 30 \mathrm{gl}^{-1} \text { sucrose solidified with } 7 \mathrm{gl}^{-1} \text { agar and } \mathrm{pH} \text { was adjusted to } 5.7-5.8 \text { and } \\
\text { autoclaved it and dispensed } 20 \mathrm{ml} \text { in sterilized condition in each sterilized } 90 \mathrm{~mm} \text { petri dish. }\end{array}$ & 3 \\
\hline 2 & $\begin{array}{l}\text { MS2 for semi-solid } \\
\text { culture }\end{array}$ & $\begin{array}{l}\text { MS salts, B5 vitamins, iron source, myo-inositol } 0.1 \mathrm{gl}^{-1} \text {, sucrose } 30 \mathrm{gl}^{-1}, 2,4-\mathrm{D} 2.5 \mathrm{mgl}^{-1} \text {, were mixed } \\
\text { and made the volume } 1 \text { litre and adjust the } \mathrm{pH} 5.6-5.8 \text { and add Agar } 8 \mathrm{gl}^{-1} \text { mixed and autoclaved it } \\
\text { and dispensed } 20 \mathrm{ml} \text { in each sterilized } 90 \mathrm{~mm} \text { petridish. }\end{array}$ & 16 \\
\hline 3 & $\begin{array}{l}\text { MS3 for suspension } \\
\text { culture }\end{array}$ & $\begin{array}{l}\text { MS salts, B5 vitamins, iron source, myo-inocitol } 0.1 \mathrm{gl}^{-1}, 2,4-\mathrm{D} 2.5 \mathrm{mgl}^{-1} \text {, STS } 29.4 \mu \mathrm{M} \text { and adjust the } \\
\text { pH } 5.6 \text { - } 5.8 \text { and autoclaved it and dispensed } 50 \mathrm{ml} \mathrm{in} \mathrm{each} \mathrm{Erlenmeyer} \mathrm{Conical} \mathrm{flasks.} \mathrm{In} \mathrm{each} \mathrm{flask} \\
\text { friable callus was put, mixed and placed on } 120 \mathrm{rpm} \text { agitated orbital shaker incubated at } 25^{\circ} \mathrm{C} \pm 2{ }^{\circ} \mathrm{C} \\
\text { and sub-cultured in every } 2 \text { weeks. }\end{array}$ & 8 \\
\hline
\end{tabular}


total phenolics in the shoot tips and zygotic embryos were determined by the FolinCiocalteu colorimetric method (Singleton \& Rossi, 1965). Estimations were carried out in triplicate and calculated from a calibration curve obtained with gallic acid. Total phenolic contents were expressed as gallic acid equivalents (mg GAE/g).

\section{HPLC separation of phenolic compounds}

Phenolic compounds were extracted from shoot tips and zygotic embryos as described by KarKacier (1998). Briefly, 2.5 grams of shoot tips were mixed with $5 \mathrm{ml}$ of HPLC-water, presence of ascorbic acid to prevent the oxidation. The mixture was homogenized by using ultratorax at $24,000 \mathrm{rpm}$ and centrifuged at $6000 \mathrm{rpm}$ for $30 \mathrm{~min}$ at ambient temperature. Then, $2.5 \mathrm{ml}$ of mixture was diluted with $2.5 \mathrm{ml}$ of HPLC water. After centrifuging at $6000 \mathrm{rpm}$, the final mixture was filtered through $0.45 \mu \mathrm{m}$ membrane filters before $20 \mu \mathrm{l}$ injections. High Pressure Liquid Chromatography (HPLC) analysis of phenolics was performed by HPLC on a Varian Model 9010 equipped with a UV-visible (Varian 9010 Model) detector and an auto sampler (Marathon). Gradient elution was performed with $5 \%$ formic acid (Merk, eluent A) and methanol (Merk, eluent $\mathrm{B}$ ), and gradient programme followed as $0-8 \min 70 \% \mathrm{~A}-30 \% \mathrm{~B}, 8-8.5 \mathrm{~min}$ $65 \% \mathrm{~A}-35 \% \mathrm{~B}, 8.5-20 \mathrm{~min} 60 \% \mathrm{~A}-40 \% \mathrm{~B}, 20-30 \mathrm{~min} 54 \% \mathrm{~A}-46 \mathrm{~B}, 30-30.5 \mathrm{~min}$ $40 \% \mathrm{~A}-60 \% \mathrm{~B}, 30.5-34.5 \min 15 \% \mathrm{~A}-85 \% \mathrm{~B}$ and $34.5-35 \min 70 \% \mathrm{~A}-30 \% \mathrm{~B}$. The UV detection was performed at $280 \mathrm{~nm}$. The elution was conducted at room temperature using a Supelco $\mathrm{C}_{18}$ column $(15 \times 4.6$ I.D. $)$, and at a flow rate of $1 \mathrm{ml} / \mathrm{min}$.

Initial identity assignment of phenolic was based on comparison retention data obtained with UV detector for standard compounds and sample compounds. Quantization was achieved by using peak areas from external calibration with standard [gallic acid, catechol, quercetin, rutin, o-coumeric acid (sigma), chlorogenic acid and $+(-)$ catechin (FluKa)] solutions. All determinations were done three times by using three different samples and data are expressed $\mu \mathrm{g} / \mathrm{g}$ fresh weight.

\subsection{Control of Browning}

\section{MS2 medium for callus (friable) development in semi-solid culture}

Shoot tips and zygotic embryos were inoculated on MS2 media (see Table 1) separately in petridish, placed them in dark condition, incubated at $25^{\circ} \mathrm{C} \pm 2^{\circ} \mathrm{C}$ for 4 months and were sub-cultured in every 2 weeks interval.

\section{MS3 medium for suspension culture}

MS3 medium (see Table 1) supplemented with different concentration of ascorbic acid i.e. 1, 2, 3, 5, $10 \mathrm{mgl}^{-1}$ were mixed and made the volume 1 litre, adjust the $\mathrm{pH} 5.6$ 5.8, dispensed into $50 \mathrm{ml}$ in each $250 \mathrm{ml}$ volume Erlenmeyer conical flask and autoclaved. In each flask friable callus was put, mixed and placed on $120 \mathrm{rpm}$ agitated orbital shaker incubated at $25^{\circ} \mathrm{C} \pm 2^{\circ} \mathrm{C}$ for 8 weeks and were sub-cultured in every 2 weeks.

\section{MS4 medium for liquid culture}

Immature or matured litchi seeds (for zygotic embryos) were cultured in culture tubes having MS4 medium (see Table 1) of $20 \mathrm{ml}$ in each culture tubes with filter bridge and placed them in standard cultural condition (light intensity $60 \mu \mathrm{E} \mathrm{m}^{-2} \cdot \mathrm{s}^{-1}$, pe- 
riod $16 \mathrm{~h} 1 / 8 \mathrm{~h} \mathrm{~d}$ and incubated at $25^{\circ} \mathrm{C} \pm 2^{\circ} \mathrm{C}$ ) for 16 weeks and were sub-cultured in every 2 weeks interval.

\section{Use of Different Chemicals for Control of Browning in Semi-Solid Culture}

\subsection{Effect of Activated Charcoal}

Different concentrations of Activated charcoal $\left(1 \mathrm{gl}^{-1}, 2 \mathrm{gl}^{-1}, 2.5 \mathrm{gl}^{-1}, 3 \mathrm{gl}^{-1}, 4.5 \mathrm{gl}^{-1}\right.$ and $5 \mathrm{gl}^{-1}$ ) were prepared and this Activated charcoal were separately added before autoclaving of MS2, after that autoclaved MS2 medium were poured in sterilized Petri plates and left it for polymerization. After solidification of medium in each Petri plates 6 shoot tips and zygotic embryos were inoculated separately in each separate petriplates and petri plates were sealed with parafilm, kept them in culture room in dark condition at $25^{\circ} \mathrm{C} \pm 2{ }^{\circ} \mathrm{C}$ temperature up to four months, sub-cultured in every 2 weeks interval and observe their effects.

\subsection{Effect of L-Cysteine $\mathrm{HCl}$}

Different concentrations ( $25 \mathrm{mM}, 50 \mathrm{mM}, 75 \mathrm{mM}, 100 \mathrm{mM}, 125 \mathrm{mM}$ and $150 \mathrm{mM}$ ) of L-cysteine $\mathrm{HCl}$ were prepared separately and were sterilized through micro filter unit. Followed by shoot tips and zygotic embryos were presoaked in this solution for $45 \mathrm{mi}$ nutes, inoculated on MS2 medium. L-cysteine $\mathrm{HCl}$ is used only in presoaking of zygotic embryos to minimize browning during excision but it is not supplemented in the medium.

\subsection{Effect of Ascorbic Acid}

\section{1) At low concentration}

Different concentrations $\left(0.025 \mathrm{gl}^{-1}, 0.050 \mathrm{gl}^{-1}, 0.075 \mathrm{gl}^{-1}, 100 \mathrm{gl}^{-1}\right.$ and $\left.150 \mathrm{gl}^{-1}\right)$ of Ascorbic acid were prepared, sterilized as above and were mixed separately into autoclaved cooled MS2 medium. After that shoot tips and zygotic embryos were inoculated separately in plates and were kept in culture room in dark condition.

\section{2) At high concentration}

All conditions and media were same as mentioned above but only Ascorbic acid was prepared of $\left(1 \mathrm{gl}^{-1}, 2 \mathrm{gl}^{-1}, 2.5 \mathrm{gl}^{-1}, 3 \mathrm{gl}^{-1}, 5 \mathrm{gl}^{-1}\right.$ and $\left.10 \mathrm{gl}^{-1}\right)$ different concentrations.

\section{3) Presoaked zygotic embryo in ascorbic acid}

Shoot tips and Zygotic embryos were presoaked in $3 \mathrm{gl}^{-1}$ Ascorbic acid solution for 2 hour and were inoculated on MS2 media with BAP $200 \mathrm{mgl}^{-1}$ and different $\left(1 \mathrm{gl}^{-1}, 2\right.$ $\mathrm{gl}^{-1}, 2.5 \mathrm{gl}^{-1}, 3 \mathrm{gl}^{-1}, 5 \mathrm{gl}^{-1}$ and $10 \mathrm{gl}^{-1}$ ) concentrations of ascorbic acid. Followed by all plates were kept into culture room in dark condition incubated at $25^{\circ} \mathrm{C} \pm 2^{\circ} \mathrm{C}$.

\subsection{Effect of Ascorbic Acid with Activated Charcoal}

Different concentrations $\left(0.025 \mathrm{gl}^{-1}, 0.050 \mathrm{gl}^{-1}, 0.075 \mathrm{gl}^{-1}, 0.100 \mathrm{gl}^{-1}\right.$ and $\left.0.150 \mathrm{gl}^{-1}\right)$ of Ascorbic acid were prepared, sterilized through filter unit and were mixed separately 
into autoclaved cooled MS2 with $2.5 \mathrm{gl}^{-1}$ Activated Charcoal medium. Followed by the inoculation of shoot tips and zygotic embryos, all plates were kept in culture room in dark condition incubated at $25^{\circ} \mathrm{C} \pm 2{ }^{\circ} \mathrm{C}$.

\subsection{Effect of Citric Acid}

1) Without presoaked shoot tips and zygotic embryos in ascorbic acid

Different concentrations $\left(1 \mathrm{gl}^{-1}, 2 \mathrm{mgl}^{-1}, 3 \mathrm{gl}^{-1}, 4 \mathrm{gl}^{-1}\right.$ and $\left.5 \mathrm{gl}^{-1}\right)$ of Citric acid were prepared, sterilized through filter unit and were mixed separately into autoclaved cooled MS2 medium and after the inoculation of shoot tips and zygotic embryos all plates were kept in culture room in dark condition at $25^{\circ} \mathrm{C} \pm 2{ }^{\circ} \mathrm{C}$.

2) Presoaked zygotic embryo in ascorbic acid

Shoot tips and Zygotic embryos were presoaked in $3 \mathrm{gl}^{-1}$ Ascorbic acid solution for 2 hour and they were inoculated on MS2 media with different concentrations $\left(1 \mathrm{gl}^{-1}, 2\right.$ $\mathrm{gl}^{-1}, 3 \mathrm{gl}^{-1}, 4 \mathrm{gl}^{-1}$ and $5 \mathrm{gl}^{-1}$ ) of Citric acid and all plates were kept in culture room in dark condition and incubated at $25^{\circ} \mathrm{C} \pm 2^{\circ} \mathrm{C}$.

\subsection{Effect of $\mathrm{AgNO}_{3}$}

Different concentrations ( $25 \mathrm{mM}, 50 \mathrm{mM}, 75 \mathrm{mM}, 100 \mathrm{mM}, 125 \mathrm{mM}$ and $150 \mathrm{mM}$ ) of $\mathrm{AgNO}_{3}$ were prepared separately and were sterilized through micro filter unit. After that both shoot tips and zygotic embryos were presoaked in this solution for 45 minutes and then were inoculated on MS2 medium supplemented with different concentration of $\mathrm{AgNO}_{3}$ and kept on dark condition incubated at $25^{\circ} \mathrm{C} \pm 2{ }^{\circ} \mathrm{C}$.

\subsection{Effect of Ascorbic Acid Along with Citric Acid}

Different concentrations of Ascorbic acid $\left(0.200 \mathrm{gl}^{-1}, 0.500 \mathrm{gl}^{-1}, 1 \mathrm{gl}^{-1}, 1.5 \mathrm{gl}^{-1}\right.$ and 2 $\mathrm{gl}^{-1}$ ) and the same concentration of Citric were prepared, mixed together separately and made the citric and ascorbic acid solution (combined). Both the explants (shoot tips and zygotic embryos) were presoaked in $0.225 \mathrm{gl}^{-1}$ citric with ascorbic acid solution and were inoculated on MS2 medium supplemented with different concentration of ascorbic acid and citric acids combined and kept on dark condition incubated at $25^{\circ} \mathrm{C} \pm 2{ }^{\circ} \mathrm{C}$.

Three replicas were made for all experiments.

\subsection{Use of Filter Bridge with Ascorbic Acid for Control of Browning in Liquid Culture}

To see the effect of filter bridge with ascorbic acid on control of browning, germinability and multiple shoot induction from zygotic embryos in liquid culture, immature or mature seeds were inoculated on MS4 medium supplemented with BAP $20 \mathrm{mgl}^{-1}$, ascorbic acid $5 \mathrm{mgl}^{-1}$ with or without filter bridge and placed them in standard cultural conditions for 4 - 6 weeks. Since zygotic embryos immature or matured during excision from seeds secretes comparatively a large amount of phenolics so that instead of zygotic embryos, immature or matured seeds were cultured on filter bridge in liquid medium which secretes comparatively less amount of phenolics. 


\subsection{Statistical Analysis}

Data for explants browning were subjected to angular transformation for normalizing the frequency distribution, prior to statistical analysis. In each experiment 6 explants for control of browning were taken in each petridish and three petridishes for each treatment and $100 \%$ of control of browning of explants' response was observed in combined effect of ascorbic and citric acids. The percentage response of calli production from explants was different in different antioxidants concentrations i.e. from 1 to 80 in semi-solid culture of six explants cultured and maximum $3 \times 10^{6}$ number of cells $/ \mathrm{ml}$ in suspension culture. The statistical significance on phenolic composition of explants (shoot tips and zygotic embryos) was calculated by one-way ANOVA followed by Tukey's multiple comparison tests. All data analyses were performed using the Graph Pad software (Graph Pad in Stat. Software Inc., San Diego, CA 92130, USA).

\section{Results and Discussion}

\subsection{Changes in the Browning Percentage of Litchi Explants}

Some of the explants cultured in vitro remained viable and grew during the establishment stage of the in vitro culture, while some of them turned dark brown. A major browning phenomenon was observed after about 12 - 14 days of inoculation. The data recorded after three weeks for the explants browning and the statistical separation of the means are given in Table 2(a) \& Table 2(b). The percentages of explants' browning changed significantly according to cultivars and the months of the explants collection $(p \leq 0.05)$. In both cultivars, the lowest percentages of explants browning were detected in the shoot tips and zygotic embryos collected in March and explants browning gradually increased during the season, with high values in Bedana. Both zygotic embryos (as immature litchi fruits) and shoot tips were collected after four weeks of anthesis (i.e. opening of flower, pollination and fertilization of egg and polar nuclei with male gametes accomplished in ovule inside ovary) in the same month i.e. March (Reproductive stage), because both inflorescences, which later developed zygotic embryos after anthesis inside immature fruit, and shoot tips, sprouted in same time during spring season. Both were used as explants in vitro culture for callus development and somatic embryogenesis from zygotic embryos and multiple shoot induction and plant regeneration from shoot tips for mass scale propagation. It has been observed that in both explants the concentration of phenolics is comparatively low in March and consequently browning which is caused by the oxidation of phenolics by Polyphenoloxidase and formed melanin pigment (brown in color), necrosis and death of explants was under control during in vitro culture. Both explants responded well in callus proliferation from zygotic embryos and multiple shoot induction from shoot tips during march but as months forward i.e. from April to June browning was comparatively higher due to increase in phenolic compounds concentration, in June it is out of control, explants showed heavy browning, necrosis and death of explants and consequently no or a few callus developed during in-vitro culture. 
Table 2. (a) Changes in the shoot tip explants browning and the phenolic compounds at different months of shoot tips explants collection; (b) Changes in the zygotic embryos explants browning and the phenolic compounds at different months of zygotic embryos explants collection.

(a)

\begin{tabular}{|c|c|c|c|c|c|c|c|c|c|c|}
\hline Cultivars & Months & $\begin{array}{c}\text { Shoot tip } \\
\text { explants } \\
\text { browning (\%) }\end{array}$ & $\begin{array}{c}\text { Total } \\
\text { phenolics } \\
(\mathrm{mg} / \mathrm{g})\end{array}$ & $\begin{array}{c}\text { Gallic acid } \\
(\mu \mathrm{g} / \mathrm{g})\end{array}$ & $\begin{array}{c}+(-) \text { catechin } \\
(\mu \mathrm{g} / \mathrm{g})\end{array}$ & $\begin{array}{c}\text { Catechol } \\
(\mu \mathrm{g} / \mathrm{g})\end{array}$ & $\begin{array}{l}\text { Chlorogenic } \\
\text { Acid }(\mu \mathrm{g} / \mathrm{g})\end{array}$ & $\begin{array}{l}\text { Rutin } \\
(\mu \mathrm{g} / \mathrm{g})\end{array}$ & $\begin{array}{l}\text { O-coumeric } \\
\text { Acid }(\mu \mathrm{g} / \mathrm{g})\end{array}$ & $\begin{array}{l}\text { Quercetin } \\
(\mu \mathrm{g} / \mathrm{g})\end{array}$ \\
\hline \multirow{2}{*}{ Purbi } & April & $65.50 \pm 0.133$ & $12.94 \pm 0.17$ & $208.69 \pm 0.12$ & $143.85 \pm 0.13$ & $142.85 \pm 0.13$ & $31.14 \pm 0.12$ & $3.60 \pm 0.12$ & $2.15 \pm 0.13$ & $2.14 \pm 0.13$ \\
\hline & May & $73.00 \pm 0.15$ & $16.54 \pm 0.29$ & $216.20 \pm 0.21$ & $243.90 \pm 0.22$ & $177.90 \pm 0.24$ & $37.79 \pm 0.23$ & $4.21 \pm 0.20$ & $1.42 \pm 0.20$ & $1.12 \pm 0.24$ \\
\hline \multirow{4}{*}{ Bedan } & March & $27.14 \pm 0.11$ & $5.11 \pm 0.18$ & $74.09 \pm 0.10$ & $38.64 \pm 0.17$ & $33.48 \pm 0.12$ & $9.80 \pm 0.18$ & $3.40 \pm 0.12$ & $1.06 \pm 0.19$ & $0.54 \pm 0.12$ \\
\hline & April & $43.00 \pm 0.16$ & $8.94 \pm 0.08$ & $175.87 \pm 0.15$ & $70.68 \pm 0.09$ & $102.65 \pm 0.15$ & $13.63 \pm 0.07$ & $4.02 \pm 0.15$ & $1.42 \pm 0.06$ & $1.10 \pm 0.17$ \\
\hline & May & $53.30 \pm 0.09$ & $11.30 \pm 0.49$ & $192.74 \pm 0.10$ & $142.80 \pm 0.48$ & $113.61 \pm 0.10$ & $13.42 \pm 0.39$ & $5.21 \pm 0.07$ & $1.34 \pm 0.38$ & $1.01 \pm 0.10$ \\
\hline & June & $70.30 \pm 0.19$ & $14.40 \pm 0.23$ & $252.43 \pm 0.18$ & $232.24 \pm 0.24$ & $155.00 \pm 0.17$ & $15.50 \pm 0.24$ & $9.28 \pm 0.18$ & $1.43 \pm 0.22$ & $1.21 \pm 0.18$ \\
\hline
\end{tabular}

(b)

\begin{tabular}{|c|c|c|c|c|c|c|c|c|c|c|}
\hline Cultivars & Months & $\begin{array}{c}\text { Zygotic embryo } \\
\text { explants } \\
\text { browning (\%) }\end{array}$ & $\begin{array}{c}\text { Total } \\
\text { phenolics } \\
(\mathrm{mg} / \mathrm{g})\end{array}$ & $\begin{array}{l}\text { Gallic acid } \\
(\mu \mathrm{g} / \mathrm{g})\end{array}$ & $\begin{array}{c}+(-) \text { catechin } \\
(\mu \mathrm{g} / \mathrm{g})\end{array}$ & $\begin{array}{c}\text { Catechol } \\
(\mu \mathrm{g} / \mathrm{g})\end{array}$ & $\begin{array}{l}\text { Chlorogenic } \\
\text { Acid }(\mu \mathrm{g} / \mathrm{g})\end{array}$ & $\begin{array}{l}\text { Rutin } \\
(\mu g / g)\end{array}$ & $\begin{array}{c}\text { O-coumeric } \\
\text { Acid } \\
(\mu \mathrm{g} / \mathrm{g})\end{array}$ & $\begin{array}{l}\text { Quercetin } \\
(\mu \mathrm{g} / \mathrm{g})\end{array}$ \\
\hline \multirow{3}{*}{ Purbi } & March & $51.80 \pm 0.18$ & $9.80 \pm 0.20$ & $91.50 \pm 0.17$ & $58.00 \pm 0.20$ & $58.03 \pm 0.18$ & $27.48 \pm 0.20$ & $2.51 \pm 0.17$ & $1.40 \pm 0.20$ & $1.14 \pm 0.18$ \\
\hline & April & $62.50 \pm 0.13$ & $12.92 \pm 0.16$ & $206.62 \pm 0.20$ & $142.86 \pm 0.15$ & $141.84 \pm 0.13$ & $30.13 \pm 0.16$ & $2.61 \pm 0.15$ & $2.14 \pm 0.13$ & $2.13 \pm 0.11$ \\
\hline & May & $71.00 \pm 0.24$ & $15.53 \pm 0.28$ & $215.20 \pm 0.18$ & $245.80 \pm 0.29$ & $176.90 \pm 0.17$ & $36.78 \pm 0.28$ & $3.11 \pm 0.25$ & $1.40 \pm 0.25$ & $1.10 \pm 0.20$ \\
\hline \multirow{4}{*}{ Bedana } & March & $26.12 \pm 0.10$ & $4.10 \pm 0.17$ & $73.07 \pm 0.11$ & $37.62 \pm 0.16$ & $32.47 \pm 0.12$ & $8.80 \pm 0.11$ & $2.42 \pm 0.10$ & $1.04 \pm 0.12$ & $0.52 \pm 0.10$ \\
\hline & April & $42.00 \pm 0.16$ & $7.93 \pm 0.09$ & $174.86 \pm 0.13$ & $69.66 \pm 0.08$ & $100.64 \pm 0.15$ & $12.62 \pm 0.14$ & $3.00 \pm 0.11$ & $1.40 \pm 0.13$ & $1.12 \pm 0.11$ \\
\hline & May & $52.30 \pm 0.08$ & $10.32 \pm 0.50$ & $190.72 \pm 0.09$ & $141.80 \pm 0.48$ & $111.61 \pm 0.10$ & $12.40 \pm 0.11$ & $4.20 \pm 0.10$ & $1.33 \pm 0.11$ & $1.04 \pm 0.12$ \\
\hline & June & $69.30 \pm 0.18$ & $13.42 \pm 0.22$ & $252.42 \pm 0.19$ & $230.23 \pm 0.20$ & $154.00 \pm 0.18$ & $14.51 \pm 0.16$ & $8.27 \pm 0.17$ & $1.42 \pm 0.16$ & $1.22 \pm 0.11$ \\
\hline
\end{tabular}

Mean value of three individual experiments showing significant ${ }^{*}$, more significant ${ }^{* *}$ and most significant ${ }^{* * *}$ respectively in both Table $2(\mathrm{a}) \&$ Table $2(\mathrm{~b})$, \pm Standard Error. Purbi ${ }^{* * *} P<0.001,{ }^{* *} P<0.01,{ }^{*} P<0.05$, Bedana ${ }^{* * *} P<0.001,{ }^{* *} P<0.01,{ }^{*} P<0.05$.

\subsection{Changes in the Total Phenolic Content of Litchi Explants}

Total phenolic contents of shoot tips and zygotic embryos in the various months are presented in Table 2(a) \& Table 2(b). Genotype and months of explants collection had significant effects on the total phenolic contents in shoot tips and zygotic embryos $(p \leq$ 0.05).

Total phenolic content in the Purbi shoot tips and zygotic embryos exhibited a low initial value in March, and then increased gradually, reaching a maximum level in June. Although Purbi showed a similar pattern for total phenolic content with Bedana, this litchi cultivar exhibited higher total phenolic contents than Bedana in all months.

\subsection{Changes in the Browning Control in Semi-Solid Culture}

No response of explants in the browning control was observed in different concentrations of activated charcoal $\left(1,1.5,2.0,2.5,3.0\right.$ and $\left.3.5 \mathrm{gl}^{-1}\right)$, pre-soaking of explants with 
or without activated charcoal in L-cysteine $\operatorname{HCl}(25,30,75,100,125$ and $150 \mathrm{mM})$, low concentration of ascorbic acid $\left(0.025,0.050,0.075,0.100,0.150 \mathrm{gl}^{-1}\right)$ and $\mathrm{AgNO}_{3}(25$, $50,75,100$ and $125 \mathrm{mM}$ ).

\subsection{Effect of Ascorbic Acid}

\section{1) At high concentration}

During soaking of explants(shoot tips/zygotic embryos) with high concentration of ascorbic acid all were fresh after inoculating them on MS2 medium supplemented with ascorbic acid, all explants were fresh and better result was observed at $3 \mathrm{gl}^{-1}$ and within 6 - 7 weeks callus formation was started (see Table 3) (Figure 1, Figure 2 \& Figure 4).

Table 3. Effect of different concentrations of ascorbic acid on both explants (shoot tips and zygotic embryos) cultured on MS2 medium.

\begin{tabular}{ccccc}
\hline & & & \multicolumn{2}{c}{ No. of explants responds } \\
\cline { 3 - 5 } Serial number & Concentration & No. of explants per plate & $\begin{array}{c}\text { Control } \\
\text { (medium without } \\
\text { ascorbic acid) }\end{array}$ & $\begin{array}{c}\text { Experiment } \\
\text { (medium with } \\
\text { ascorbic acid) }\end{array}$ \\
\hline 1 & $1 \mathrm{gl}^{-1}$ & 6 & No & No \\
2 & $2 \mathrm{gl}^{-1}$ & 6 & No & 1 \\
3 & $2.5 \mathrm{gl}^{-1}$ & 6 & No & 3 \\
4 & $3 \mathrm{gl}^{-1}$ & 6 & No & 4 \\
5 & $5 \mathrm{gl}^{-1}$ & 6 & No & 2 \\
\hline
\end{tabular}

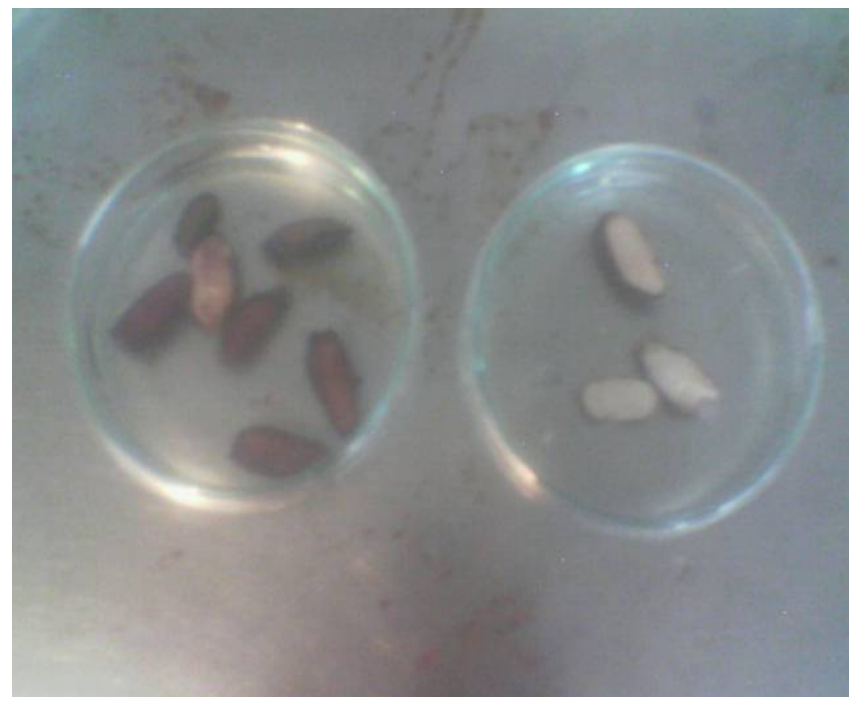

(a)

(b)

Figure 1. Effect of ascorbic acid on zygotic embryos in semi-solid culture. (a) Zygotic embryos without ascorbic acid in medium so that they turned brown due to over-secretion of polyphenilics; (b) Zygotic embryos with ascorbic acid ( $3 \mathrm{gl}^{-1}$, high concentration) in the medium were fresh due to no secretion of polyphenolics. 


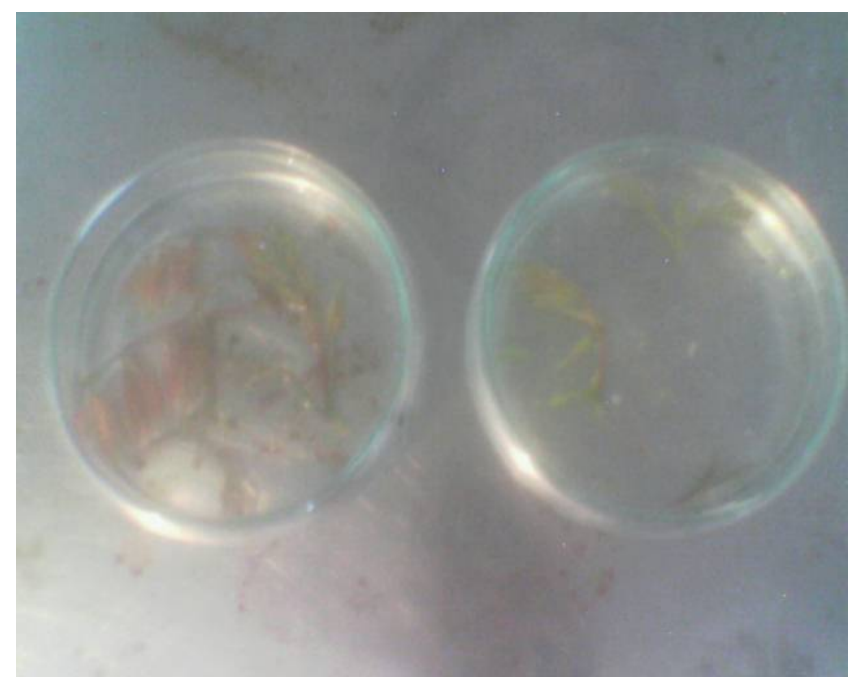

(a)

(b)

Figure 2. Effect of ascorbic acid on shoot tips in semi-solid culture. (a) Shoot tips without ascorbic acid in medium so that they turned brown due to over-secretion of polyphenolics; (b) Shoot tips with ascorbic acid ( $3 \mathrm{gl}^{-1}$, high concentration) in the medium were fresh due to secretion of polyphenolics.

\section{2) Ascorbic acid with activated charcoal}

Explants were showing fresh next two weeks after the culturing on MS2 medium supplemented with both ascorbic acid and charcoal, but after two weeks it turned into pale and gradually browning was appeared. Best result was observed at $2.5 \mathrm{gl}^{-1}$ and 3.5 $\mathrm{gl}^{-1}$ and formation of callus taken place (see Table 4).

\subsection{Effect of Citric Acid}

After culturing of explants (shoot tips/zygotic embryos) on MS2 medium supplemented with different concentration of citric acid, all were fresh but after three weeks in turned into pale, but presoaking of explants on citric acid and again culture on MS2 medium with same condition all were fresh and formation of somatic embryos were taken place (see Table 5).

\subsection{Effect of Ascorbic Acid with Citric Acid}

All explants (shoot tips/zygotic embryos) when cultured on MS2 medium supplemented with combined different concentrations of ascorbic acid and citric acid, were fresh and formation of somatic embryos started and best result was observed at $1 \mathrm{gl}^{-1}$ $1.5 \mathrm{gl}^{-1}$ concentration of ascorbic with citric acid (see Table 6).

\subsection{Effect of Filter Bridge with Ascorbic Acid on Control of Browning in Liquid Culture}

It was observed that following 4 - 6 weeks immature or matured seeds (for zygotic embryos) cultured on MS4 medium (liquid) on filter bridge they induces about 6 - 9 multiple shoots on cotyledonary node in presence of less concentration of ascorbic acid 5 
Table 4. Effect of ascorbic acid with activated charcoal on both explants (shoot tips/zygotic embryos) supplemented in MS2 medium and both explants were cultured separately in separate petridish and each petridish has six explants.

\begin{tabular}{ccccccc}
\hline & & \multicolumn{2}{c}{ No. of explants responds } & \multicolumn{2}{c}{ \% of calli formation } \\
\cline { 5 - 7 } $\begin{array}{c}\text { Serial } \\
\text { Number }\end{array}$ & Concentration & $\begin{array}{c}\text { No. of } \\
\text { explants } \\
\text { per plate }\end{array}$ & $\begin{array}{c}\text { Control-1 } \\
\text { (medium without } \\
\text { ascorbic acid and } \\
\text { activated charcoal) }\end{array}$ & $\begin{array}{c}\text { Experiment-1 } \\
\text { (medium with } \\
\text { ascorbic acid } \\
\text { activated charcoal) }\end{array}$ & $\begin{array}{c}\text { Control-2 } \\
\text { (same as 1) }\end{array}$ & $\begin{array}{c}\text { Experiment-2 } \\
\text { (same as 1) }\end{array}$ \\
\hline 1 & $0.025 \mathrm{gl}^{-1}$ & 6 & No & No & No & 0 \\
2 & $0.050 \mathrm{gl}^{-1}$ & 6 & No & 1 & No & 16 \\
3 & $0.075 \mathrm{gl}^{-1}$ & 6 & No & 2 & No & 33.3 \\
4 & $0.100 \mathrm{gl}^{-1}$ & 6 & No & 1 & No & 16 \\
5 & $0.150 \mathrm{gl}^{-1}$ & 6 & No & No & No & No \\
\hline
\end{tabular}

Table 5. Effect of citric acid on both explants (shoot tips/zygotic embryos) browning cultured on MS2 medium supplemented with different concentrations of citric acid and both explants were cultured separately in separate petridish and each petridish has six explants.

\begin{tabular}{ccccccc}
\hline & & & \multicolumn{2}{c}{$\begin{array}{c}\text { \% of explants } \\
\text { responds without soaking }\end{array}$} & \multicolumn{2}{c}{$\begin{array}{c}\text { \% of explants } \\
\text { responds after soaking }\end{array}$} \\
\cline { 4 - 7 } Sumber & concentration & $\begin{array}{c}\text { No. of } \\
\text { explants }\end{array}$ & $\begin{array}{c}\text { Control } \\
\text { (without soaking } \\
\text { and addition in } \\
\text { the medium) }\end{array}$ & $\begin{array}{c}\text { Experiment } \\
\text { (with soaking } \\
\text { and addition in } \\
\text { the medium) }\end{array}$ & $\begin{array}{c}\text { Control } \\
\text { (medium without } \\
\text { citric acid) }\end{array}$ & $\begin{array}{c}\text { Experiment } \\
\text { (medium with } \\
\text { citric acid) }\end{array}$ \\
\hline 1 & $1 \mathrm{gl}^{-1}$ & 6 & No & No & No & 16 \\
2 & $2 \mathrm{gl}^{-1}$ & 6 & No & No & No & 40 \\
3 & $3 \mathrm{gl}^{-1}$ & 6 & No & 33.3 & No & 60 \\
\hline 5 & $4 \mathrm{gl}^{-1}$ & 6 & No & 25 & No & 45 \\
\hline
\end{tabular}

Table 6. Combined effect of ascorbic and citric acids on both explants (shoot tips and zygotic embryos) browning cultured on MS2 medium supplemented with different concentrations of ascorbic and citric acids and both explants were cultured separately in separate petridish and each petridish has six explants.

\begin{tabular}{ccccccc}
\hline & & \multicolumn{2}{c}{ No. of explants responds } & \% of calli formation \\
\cline { 5 - 7 } $\begin{array}{c}\text { Serial } \\
\text { Number } \begin{array}{c}\text { Concentration } \\
\text { of both ascorbic } \\
\text { and citric acids }\end{array}\end{array}$ & $\begin{array}{c}\text { No. of } \\
\text { explants }\end{array}$ & $\begin{array}{c}\text { Control-1 } \\
\text { (without ascorbic } \\
\text { and citric acids in } \\
\text { the medium) }\end{array}$ & $\begin{array}{c}\text { Experiment-1 } \\
\text { (with ascorbic and citric } \\
\text { acid in the medium) }\end{array}$ & $\begin{array}{c}\text { Control-2 } \\
\text { (same as 1) }\end{array}$ & $\begin{array}{c}\text { Experiment-2 } \\
\text { (same as 1) }\end{array}$ \\
\hline 1 & $0.200 \mathrm{gl}^{-1}$ & 6 & No & 1.5 & No & 16 \\
2 & $0.500 \mathrm{gl}^{-1}$ & 6 & No & 2.0 & No & 33.3 \\
3 & $1.00 \mathrm{gl}^{-1}$ & 6 & No & 3.0 & No & 50 \\
4 & $1.500 \mathrm{gl}^{-1}$ & 6 & No & 4.0 & No & 80 \\
5 & $2.00 \mathrm{gl}^{-1}$ & 6 & No & 3.5 & No & 45 \\
\hline
\end{tabular}


$\mathrm{mgl}^{-1}$ browning was controlled may be due to settling down of phenolics on filter bridge and also in liquid medium. Those seeds which were cultured in the medium without filter bridge shoot buds were not induced on cotyledonary node. It was also observed that following 4 - 6 weeks Filter Bridge were turned brown may be due to binding of phenolics on filter bridge (Das et al., 1999a, b) (Figure 3).

\subsection{Changes in the Browning Control in Cell Suspension Culture}

Cells grown in suspension culture both from shoot tips and zygotic embryos separately in MS 3 liquid medium were fresh at $2 \mathrm{mgl}^{-1}$ concentration of ascorbic acid. The cells were observed growing very fast and cells were fresh. The secretion of phenolics in the medium was also controlled but both in lower and higher concentration of ascorbic acid a small number of cells were grown and degree of control of browning was less effective. In control where ascorbic acid was not added in the medium both cells and medium were turned brown (see Table 7) (Figure 4).

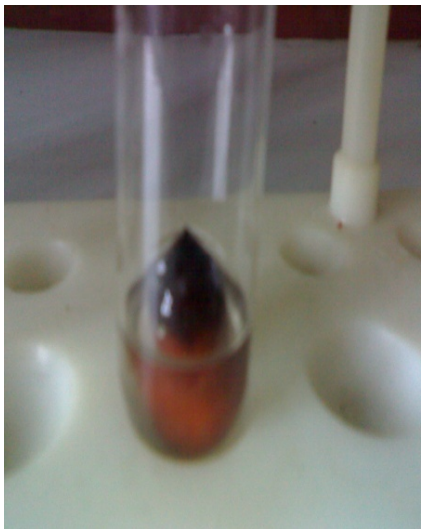

(a)

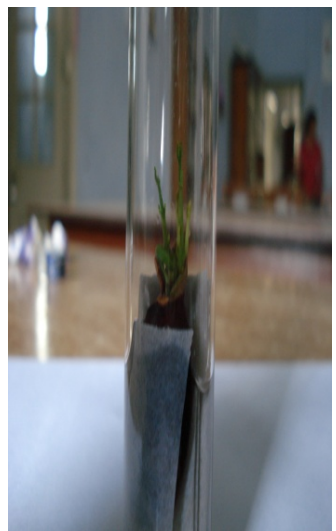

(b)

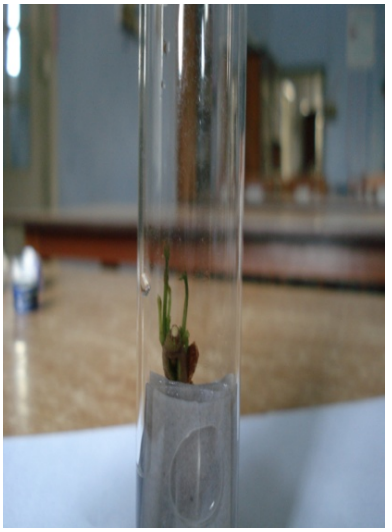

(c)

Figure 3. Effect of Filter Bridge with ascorbic acid on control of browning. (a) Seeds cultured in liquid medium without Filter Bridge, no shoot buds were induced; (b) \& (c) Seeds were cultured in liquid medium with filter bridge, a large number of shoot buds were produced may be due to binding of polyphenolics to filter bridge and control of browning.

Table 7. Effect of different concentrations of ascorbic acid on cells obtained from zygotic embryos in suspension culture in MS3 liquid medium.

\begin{tabular}{|c|c|c|c|}
\hline \multirow{2}{*}{$\begin{array}{c}\text { Serial } \\
\text { Number }\end{array}$} & \multirow{2}{*}{$\begin{array}{l}\text { Concentration of } \\
\text { ascorbic } \\
\text { acid }\left(\mathrm{mgl}^{-1}\right)\end{array}$} & \multicolumn{2}{|c|}{ No. of cells/ml in suspension culture } \\
\hline & & $\begin{array}{l}\text { Control } \\
\text { (without ascorbic acid in the medium) }\end{array}$ & $\begin{array}{c}\text { Experiment } \\
\text { (with ascorbic acid in the medium) }\end{array}$ \\
\hline 1 & 0 & No & $1 \times 10^{3}$ \\
\hline 2 & 1 & No & $1 \times 10^{6}$ \\
\hline 3 & 2 & No & $3 \times 10^{6}$ \\
\hline 4 & 3 & No & $1 \times 10^{3}$ \\
\hline 5 & 5 & No & $1 \times 10^{2}$ \\
\hline 6 & 10 & No & $1 \times 10^{1}$ \\
\hline
\end{tabular}




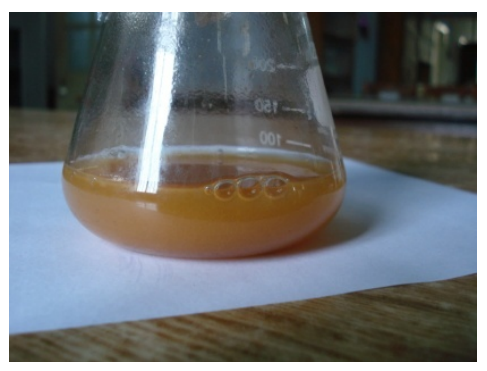

(a)

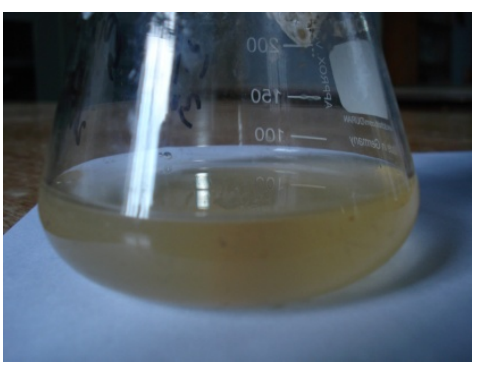

(b)

Figure 4. Effect of ascorbic acid in cell suspension culture. (a) Cell suspension culture without ascorbic acid so that cells were brown, necroses and dead; (b) Cell suspension culture with ascorbic acid $\left(2 \mathrm{mgl}^{-1}\right)$ so that cells were fresh and fast dividing.

\section{Role of antioxidants on browning control}

Activated charcoal has large number of pore \& active binding sites for polyphenols and for other compounds in most of the cases it was observed that it was able to control browning as well as inhibitory compounds but in the case of litchi activated charcoal alone was not found able to control the browning and it could be due to binding with some nutrients also.

Ascorbic acid is a potent antioxidant it has been frequently used for browning control (Toth et al., 1993), it reduced the polyphenoloxidase activity in the case of litchi can check the browning when explants presoaked into ascorbic acid solution just after the excision of zygotic embryo and culture it at high concentration on ascorbic acid with or without activated charcoal because embryo secretes large amount of phenolic compounds just after incision of explants.

The combination of ascorbic with citric acid acts as a powerful antioxidant it may inhibit the polyphenoloxidase activity and also serve as a vitamin so that it is able to check the browning and initiate proliferation of cells and somatic embryo arises from explants.

It was observed that when explants of Pistachio species was 15 min. soaked in Lcysteine $\mathrm{HCl}$ at $100 \mathrm{mM}$ before the culturing it eliminates the browning (Gannoun et al., 1995, Tabiyeh et al., 2006) as well as increases the shoot bud formation but when this treatment applied for Litchi initially all explants were fresh but after the one week browning appeared gradually.

$\mathrm{AgNO}_{3}$ is an ethylene inhibitor and inducer for adventitious shoot bud formation (Rouston et al., 2008) as well as control the browning of Pistachio. But in case of Litchi it was observed that it is not effective to check the browning.

Finally it was observed that both excision and incision of zygotic embryos and shoot tips under axenic condition and use of ascorbic acid $2.5 \mathrm{gl}^{-1}$ with activated charcoal 2 $\mathrm{gl}^{-1}$, ascorbic acid $3 \mathrm{gl}^{-1}$ after pre soaking in $3 \mathrm{gl}^{-1}$ ascorbic acid solution and a combination of ascorbic acid $1.5 \mathrm{gl}^{-1}$ and citric acid $1.5 \mathrm{gl}^{-1}$ pre soaking in $3 \mathrm{gl}^{-1}$ ascorbic acid solution and frequent sub-culturing in semi-solid culture can eliminate the browning and reduced the polyphenoloxidase activity of Litchi. But in contrary, suspension culture browning could be controlled at very low concentration of ascorbic acid than the 
semi-solid culture could be due to cells are in direct contact of medium having ascorbic acid (antioxidants) and absorbs from whole cells surface but if concentration will increase up to $10 \mathrm{mgl}^{-1}$ then browning couldn't be controlled by ascorbic acid could be due to attainment of inhibitory action of ascorbic acid in suspension culture.

\subsection{Changes in the Phenolic Compounds of Litchi Shoot Tips and Zygotic Embryos Explants}

The amounts and variations of phenolic compounds in the shoot tips and zygotic embryos collected in the different months are presented in Table 2(a) \& Table 2(b). The genotype as well as the month of explants collection seemed to the major factors influencing the relative concentration of the various phenolic compounds in the shoot tips and zygotic embryos. In both cultivars, the various phenolic compounds quantified in this study showed significantly differences in shoot tips and zygotic embryos collected in different months $(p \leq 0.05)$.

Gallic acid and $+(-)$ catechin were the most abundant phenolic compounds in the shoot tips and zygotic embryos in both cultivars, with higher concentration in Purbi. In both cultivars, the lowest concentrations for gallic acid were found in the shoot tips and zygotic embryos collected in March. But gallic acid concentration increased at different rates up to June. Concentrations of $+(-)$ catechin in Purbi shoot tips and zygotic embryos significantly increased from March to May but there was no any significant difference for $+(-)$ catechin between May to June. In Bedana $+(-)$ catechin also showed a gradual increase during the season and the highest value was detected in the shoot tips and zygotic embryos collected in June. The amounts of the second most abundant phenolic compounds in shoot tips and zygotic embryos were catechol and chlorogenic acid. In Purbi, catechol concentration was relatively low in the shoot tips and zygotic embryos collected in March. But it subsequently exhibited a strong increase in the explants collected in April. After that this increase, but more slightly, continued up to June. Bedana also exhibited almost similar pattern with Purbi for $+(-)$ catechin. Concentrations of chlorogenic acid in the shoot tips and zygotic embryos were higher in Purbi than Bedana, in all months. While concentration of chlorogenic acid in Purbi did not significantly vary in the shoot tips and zygotic embryos collected in March, April and June, it showed a significantly increase in June. Although a lower chlorogenic acid concentration in Bedana was found in the shoot tips and zygotic embryos collected in June compared the shoot tips and zygotic embryos collected in the previous months, the values did not differ significantly. The amounts of rutin in Purbi remained almost stable from March to May, but it showed a strong increase in the shoot tips and zygotic embryos collected in June. On the other hand in Bedana concentration of rutin gradually increased during summer and reached to maximum value in June. Concentration of o-coumaric acid in shoot tips and zygotic embryos of Bedana gradually increased during summer as it showed a sharp decrease from March to June in Purbi. The highest concentration of quercetin in Purbi was found in the shoot tips and zygotic embryos collected in April, and there was no any significant difference among the other month. 
Quercetin content of Bedana had a different pattern to that of Purbi. Although it differed slightly from March to June, these differences were not significant.

\subsection{Correlation of the Phenolic Compounds with the Browning Percentage of Litchi Explants}

Correlation coefficients between the explants browning and the phenolic compounds were given in Table 8. The most remarkable positive correlation was found between explants browning and the total phenolic content. Gallic acid, $+(-)$ catechin, catechol and chlorogenic acid in the explants exhibited a significantly strong positive correlation with the explants browning. But explants browning showed relatively weak positive relationship with rutin. Neither the concentration of o-coumeric acid, nor that of quercetin showed a significant relationship with the explants browning.

Browning and subsequent death of explants is a common problem in cultures of woody plants and has generally been attributed to the oxidation of phenolic compounds in explants tissues ( $\mathrm{Hu} \&$ Wang, 1983). Browning is of considerable importance, because it invariably leads to the death of the explants.

In this study, it was determined that the browning percentages of explants varied significantly depending on the cultivars. Shoot tips and zygotic embryos of Purbi exhibited higher explants browning than those of Bedana when their percentages were compared in the same months. It has been observed that the explants browning is highly genotype dependent, as previously reported by Tangolar et al. (1999), Thomas \& Ravindra (1997) and Yu \& Meredith (1986).

Time of explants collection is in general a critical factor in explants browning (Dalal et al., 1993; Dhar \& Upreti, 1999; Tangolar et al., 1999; Thomas \& Ravindra, 1997). In both cultivars, the lowest explants browning percentages were found in the shoot tips and zygotic embryos collected in March> Shoot tips and zygotic embryos collected in the other months showed more browning, turned brown sooner and showed no growth response similar reported by Baydar, 2006 in grapevine. But Fanizza et al. (1984) in grapevine, Roussos \& Pontikis (2001a, b) in olive found that season of explants collection did not influence the explants browning.

Table 8. Correlation coefficients between phenolic compounds and explants browning.

\begin{tabular}{cc}
\hline Endogenous compounds & Explant browning \\
\hline Total phenolic content & $0.9835^{* * *}$ \\
Gallic acid & $0.8648^{* * *}$ \\
$+(-)$ catechin & $0.9196^{* * *}$ \\
Catechol & $0.9148^{* * *}$ \\
Chlorogenic acid & $0.7740^{* * *}$ \\
Rutin & $0.6054^{*}$ \\
o-coumaric acid & $\mathrm{ns}$ \\
Quercetin & $\mathrm{ns}$ \\
\hline
\end{tabular}

${ }^{*} P \leq 0.05,{ }^{* *} P \leq 0.0001, \mathrm{~ns}:$ not significant, $\mathrm{n}=84$. 
Time of explants collection influences not only the percentage of explants browning but also the contents of total phenolics (Dalal et al., 1993). In this study, it was shown a variation of explants browning and total phenols in relation to months of explants collection. The lowest browning percentages were achieved from the explants taken in March, with the highest browning percentages from those collected in June. Higher phenolic levels were associated with higher explants browning but lower survival. It was previously reported that season could an important role in the successful establishment of explants in in-vitro culture (Dhar \& Upreti, 1999) and explants survival was inversely related to phenolic content of explants (Block \& Lankes, 1995; Dalal et al., 1992; Ziv \& Halevy, 1983). Similarly, higher phenolic content and explants browning were observed with Purbi shoot tips and zygotic embryos while Bedana shoot tips and zygotic embryos showed phenolic contents and better survival.

Time of explants collection is one of the major factors influencing the relative concentration of the various phenolic compounds (Roussos \& Pontikis, 2001a). In this study, phenolic compounds quantified by HPLC presented significant differences depending on the cultivars and the months. While some of the phenolic compounds including gallic acid, $+(-)$ catechin, catechol and chlorogenic acid showed highly positive correlations with explants browning, rutin exhibited more slightly correlation with the browning. On the other hand, there were not found any correlation between browning and some phenolics such as o-coumeric acid and quercetin. Different quinones produced by different phenolic compounds contribute to a different degree to the formation of the brown color (Richard-Forget et al., 1992). In Olive explants, Roussos and Pontikis, 2001a found significantly positive correlations between some phenolic compounds (luteolin-7-glucoside, quercetin and luteolin) and the browning while they did not found any correlation between browning and some phenolics including rutin, chlorogenic acid and oleuropein.

The concentrations of the different phenolic compounds change during the growing season, presenting the great effect of environmental conditions on the total phenol content of a tissue and especially on individual phenolic compounds (Lux-Endrich et al., 2000). It is well known that the environmental properties, especially temperature and sunlight have important contribution in the formation of the phenolic compounds in plant tissues (Tangolar et al., 1999; Yu \& Meredith, 1986).

There are a lot of studies conducted on determine the effects of some factors such as genotype, explants origin, season, vigour of litchi and sunlight, on the total phenolic content and explants survival in different plants (Dalal et al., 1993; Fanizza et al., 1984; Roussos \& Pontikis, 2001a, b; Tangolar et al., 1999; Thomas \& Ravindra, 1997; Yu \& Meredith, 1986). But according to our knowledge, variabilities in the individual phenolic compounds of shoot tips and zygotic embryos and their effects on the success of shoot tip and zygotic embryos culture were not previously examined in litchi. We have found that in shoot tips and zygotic embryos of litchi there are important relationships between phenolic compounds and explants browning in the initial stage of cultures. And not only the variation of phenolic compounds but also the percentage of explants 
browning are related strongly to months of explants collection. So by the careful selection of months browning may be alleviated and thus it is possible to increase the success of shoot tips and zygotic embryos cultures of litchi.

\section{Conclusion}

It is concluded that during excision, explants secrete a lot of polyphenolics which in contact of oxygen turn into brown due to the action of polyphenol oxidase and consequently browning and death of tissue which stops the in-vitro works in litchi. This problem has been solved by the use of antioxidants in combined form (Ascorbic acid + Citric acid $250 \mathrm{mg} / \mathrm{l}$ ) and consequently controlled the browning and became possible to do in-vitro work on litchi for genetic manipulation.

\section{Acknowledgements}

Authors are grateful to the University Grants Commission, Govt. of India, New Delhi for providing financial assistance. Authors are also thankful to Dr. V.K. Tiwari, NIHFW, New Delhi for statistical analysis of various data.

\section{References}

Benson, E. E., \& Roubelakis-Angelakis, K. A. (1992). Oxidative Stress in Recalcitrant Tissue Cultures of Grapevine. Plant Science, 84, 83-90. http://dx.doi.org/10.1016/0168-9452(92)90211-4

Bhat, S. R., \& Chandel, K. P. S. (1991) A Novel Technique to Overcome Browning in Tissue Culture. Plant Cell Reports, 10, 358-361. http://dx.doi.org/10.1007/BF00193159

Block, R., \& Lankes, C. (1995). Gartenbauwissenschaft, 60, 276-279.

Chanana, Y. R., \& Gill, M. I. S. (2008). General Horticulture, Propagation and Nursery Management.

Chandra, R., \& Padari, J. C. (1999). Litchi Shoots Bud Culture for Micropropagation. Journal of Applied Horticulture, 1, 38-40.

Chew, P. C., Mardaleni Normah, M. N., \& Clyde, M. M. (2008). Activated Charcoal Is Crucial for Successful Micropropagation of Rambutan (Nephelium lappaceum Linn.). Malaysian Applied Biology, 37, 11-20.

Dalal, M. A., Sharma, B. B., \& Rao, M. S. (1992). Mode in Control of Oxidative Browning in Vitro Cultures of Grapevine. Scientia Horticulturae, 51, 35-41. http://dx.doi.org/10.1016/0304-4238(92)90101-H

Dalal, M. A., Sharma, B. B., \& Grupta, N. (1993). In Vitro Regeneration of a Mature Leguminous Lians (Bauhinia vahli Wight and Arnott). Indian Journal of Agricultural Sciences, 63, 75-79.

Das, D. K., Shiva Prakash, N., \& Sarin, N. B. (1999a) Multiple Shoot Induction and Plant Regeneration of Litchi (Litchi chinensis Sonn.). Plant Cell Reports, 18, 619-695.

http://dx.doi.org/10.1007/s002990050644

Das, D. K., Shiva Prakash, N., \& Sarin, N. B. (1999b). Multiple Shoot Induction in Litchi chinensis. A Tropical Tree Species. In P. B. Kavi Kishore (Ed.), Plant Tissue Culture and Biotechnology: An Emerging Trends (pp. 166-169). Hyderabad: Sangam Books Ltd.

Das, D. K., Reddy, M. K., Upadhyaya, K. C., \& Sopory, S. K. (2002). An Efficient Leaf Disc Culture Method for Regeneration via Somatic Embryogenesis and Transformation of Grape (Vitis vinifera L.). Plant Cell Reports, 20, 999-1005. http://dx.doi.org/10.1007/s00299-002-0441-4 
Dhar, U., \& Upreti, J. (1999). In Vitro Regeneration of a Mature Leguminous Liana (Bauhinia vahli Wight and Arnott). Plant Cell Reports, 18, 664-669.

http://dx.doi.org/10.1007/s002990050639

Fanizza, G., Tanzarella, O. A., Carrozzo, G., \& Greco, B. (1984). Methylated DNA Changes Associated with the Initiation and Maintenance of Vitis vinifera in Vitro Shoot and Callus Cultures: A Possible Mechanism for Age Related Changes. Annals of Applied Biology, 104, 577-578. http://dx.doi.org/10.1111/j.1744-7348.1984.tb03042.x

Gannoun, S., Lionakis, S. M., \& Gerasopoulos, D. (1995). Aspects of in Vitro Culture of Pistacia terebinthus and Pistacia vera. In N. Kaska, A. B. Küden, L. Ferguson, \& T. Michailides (Eds.), I International Symposium on Pistachio. ISHS Acta Horticulturae 419.

http://dx.doi.org/10.17660/actahortic.1995.419.32

Harding, K., \& Roubelakis-Angelakis, K. A. (1994). The Isolation and Purification of DNA from Vitis vinifera L. Plants and In-Vitro Cultures. Vitis, 33, 247-248.

Hu, C. Y., \& Wang, P. J. (1983). D. A. Evans, W. R. Sharp, P. V. Ammirato, \& Y. Yamada (Eds.), Handbook of Plant Cell Culture (Vol. 1, pp. 177-227). New York: Macmillan.

Kantharajah, A. S., McConchie C. A., \& Dodd W. A. (1992). In Vitro Embryo Culture and Induction of Multiple Shoots in Lychee (Litchi chinensis Sonn.). Annals of Botany, 70, 153-156.

Karkacier, M. (1998). Trabzon Hurmasimin (Diospyros kaki L.) Kimyasal Bile Imifizerinearafirmalar (p. 95). PhD Thesis, Ankara: Ankara Universitesi Fen Bilimleri Enstitusu.

Kotsias, D., \& Roussos, P. A. (2001). An Investigation on the Effect of Different Plant Growth Regulatory Compounds in in-Vitro Shoot Tip and Node Culture of Lemon Seedlings. Scientia Horticulturae, 89, 115-128. http://dx.doi.org/10.1016/S0304-4238(00)00227-2

Krishna, H. (2008). Mango Tissue Culture, Constraints and Prospects. Agricultural and Biological Sciences.

Lux-Endrich, A., Treutter, D., \& Feucht, W. (2000). Influence of Nutrients and Carbohydrate Supply on the Phenol Composition of Apple Shoots Culture. Plant Cell, Tissue and Organ Culture, 60, 15-21. http://dx.doi.org/10.1023/A:1006406527242

Mishra, D. S., Tiwari, J. P., \& Shant, L. (2007). In Vitro Cloning of Guava (Psidium guajava L.) cv. Pant Prabhat. ISHS Acta Horticulturae, 735, I53-157. http://dx.doi.org/10.17660/actahortic.2007.735.16

Murashige, T., \& Skoog, F. (1962). A Revised Medium Rapid Growth and Bioassays with Tobacco Tissue Cultures. Physiologia Plantarum, 15, 473-497. http://dx.doi.org/10.1111/j.1399-3054.1962.tb08052.x

Olhoft, P. M., \& Somers, D. A. (2001). L-Cysteine Increases Agrobacterium Mediated T-DNA Delivery into Soybean Cotyledonary-Node Cells. Plant Cell Reports, 20, 706-711.

http://dx.doi.org/10.1007/s002990100379

Puchooa, D. (2004). In Vitro Regeneration of Lychee (Litchi chinensis Sonn.). African Journal of Biotechnology, 3, 576-584.

Rasar, S., George, A. P., \& Kantharajah, A. S. (1995). Tissue Culture of Annona spp. (Chenimoya Atemoya, Sugar Apple and Soursop): A Review. Scientia Horticulturae, 62, 1-14. http://dx.doi.org/10.1016/0304-4238(94)00758-8

Richard-Forget, C. F., Ronet-Mayer, M., Goupy, M. P., Philippon, J., \& Nicolas, J. J. (1992) Cysteine as an Inhibitor of Enzymatic Browning II Kinetic Studies. Journal of Agricultural and Food Chemistry, 40, 2114-2122. http://dx.doi.org/10.1021/jf00023a015

Roussos, P. A., \& Pontikis, C. A. (2001a). Colorimetry of Total Phenolics with Phosphomolybdic-Phosphotungstic Acid Reagents. Journal of Horticultural Science and Biotechnology, 76, 
441-446. http://dx.doi.org/10.1080/14620316.2001.11511391

Roussos, P. A., \& Pontikis, C. A. (2001b) Phenolic Compounds in Olive Explants and Their Contributions to Browning during the Establishment Stage in Vitro. Gartenbauwissenschaft, 66, 298-303.

Rouston, J. P., Latche, A., \& Fallot, J. (2008). Enhancement of Shoot Regeneration from Cotyledons of Cucumis melo by $\mathrm{AgNO}_{3}$, an Inhibitor of Ethylene Action. Journal of Plant Physiology, 140, 485-488. http://dx.doi.org/10.1016/S0176-1617(11)80830-8

Sarin, N. B., Prasad, U. S., Kumar, M., \& Jain, S. M. (2008). Litchi Breeding for Genetic Improvement. In S. Mohan Jain, \& P. M. Privadarshan (Eds.), Breeding Plantation Tree Crops, Tropical Species (pp. 217-245). Berlin: Springer.

Singleton, V. L., \& Rossi, J. R. (1965). Shoot Tip Culture in Mango, Influence of Medium Genotype Explants Factors, Seasons and Decontamination on Phenolic Exudation Explants Survival and Axenic Culture Establishment. American Journal of Enology and Viticulture, 16, 144-158.

Sun, J., Xiang, X., Yu, C. Y., Shi, J. Y., Peng, H. X., Yang, B., Yang, S. Y., Yang, E., \& Jiang, Y. (2009). Variations in Contents of Browning Substrates and Activities of Some Related Enzymes during Litchi Fruit Development. Scientia Horticulturae, 120, 555-559.

http://dx.doi.org/10.1016/j.scienta.2008.12.006

Tabiyeh, D. T., Bernard, F., \& Shacker, H. (2006). Investigation of Glutathione, L-Cysteine, Sajlicylic Acid and GA3 Effects on Browning in Pistacia vera Shoot Tips Culture. In A. Javanshah, E. Facelli, \& M. Wirthensohn (Eds.), IV International Symposium on Pistachios and Almonds. ISHS Acta Horticulturae 726.

Tangolar, S., Buyukia, N., Gok, S., \& Ergenoglu, F. (1999). Turkiye III (pp. 383-388). Ulusal Bahce Bitkileri Kongresi, 14-17 Eylul 1999, Ankara.

Thomas, P., \& Ravindra, M. B. (1997). Shoot Tip Culture in Mango; Influence of Medium, Genotype, Explant Factors, Season and Decontamination Treatments on Phenolic Exudation, Explant Survival and Axenic Culture Establishment. Horticultural Science, 72, 713-722. http://dx.doi.org/10.1080/14620316.1997.11515563

Toth, K., Haapala, T., \& Hohtola, A. (1993) Alleviation of Browning in Oak Explants by Chemical Pretreatments. Biologia Plantarum, 36, 511-517. http://dx.doi.org/10.1007/BF02921170

Yu, D., \& Meredith, C. P. (1986). The Influence of Explants Origin on Tissues Browning and Shoot Production in Shoot Tip Cultures of Grapevine. Journal of the American Society for Horticultural Science, 111, 972-975.

Ziv, M., \& Halevy, A. H. (1983). Control of Oxidative Browning and in Vitro Propagation of Shaliziareginae. Horticultural Science, 18, 434-436. 
Submit or recommend next manuscript to SCIRP and we will provide best service for you:

Accepting pre-submission inquiries through Email, Facebook, LinkedIn, Twitter, etc.

A wide selection of journals (inclusive of 9 subjects, more than 200 journals)

Providing 24-hour high-quality service

User-friendly online submission system

Fair and swift peer-review system

Efficient typesetting and proofreading procedure

Display of the result of downloads and visits, as well as the number of cited articles

Maximum dissemination of your research work

Submit your manuscript at: http://papersubmission.scirp.org/

Or contact aa@scirp.org 